\title{
Property Rights Theory and Ownership of Firm- Specific Advantages: The Implications of Contracting and Licensing within the Multinational Firm
}

Catherine Magelssen

Ph.D. awarded by Rutgers University, USA (October 2014)

\section{Introduction}

The management of intangible assets such as technologies, brands, manufacturing processes, expertise, and know-how is a central part of firm strategy. Intangible assets, referred to as firm-specific advantages (FSAs), provide the firm with a competitive advantage - they are the proprietary assets that set firms apart from their competitors and enable them to earn above normal returns. Although it is generally assumed that FSAs are a public good that can be leveraged freely within the firm (e.g., Ethier, 1986), multinational firms (MNEs) allocate ownership rights to their FSAs within the firm. The entities (parent and/or subsidiaries) that hold economic ownership rights to the FSAs (FSA owners) internally contract other entities (FSA users) within the firm to perform activities such as research and development, manufacturing, and distribution. The FSA owners pay the FSA users a guaranteed normal return for their activities. Subsidiaries with ownership rights maintain control over the FSAs, make strategic decisions regarding the FSAs, and receive the income from the FSAs. The internal allocation of property rights to FSAs is a formal means of delegating control and affects the distribution of power, incentives, and resource allocation within the firm. While many researchers have studied the external licensing and contracting relationships, the internal licensing and contracting relationships have thus far been unexplored. The lack of research in this area is no doubt due to the lack of available data.

A natural question arises as to whether internal FSA ownership and the contracting relationships that ensue are simply an artifact of tax avoidance. Recent US Senate hearings on Apple and UK Parliamentary hearings on Starbucks, Amazon, and Google have captured the public's attention and highlighted the role of shifting ownership of FSAs offshore as a means of avoiding taxes (Levin \& McCain, 2013; Bergin, 2012; Thompson, 2012). In my research, I observe large differences in MNE FSA ownership strategies. While some MNEs have FSA-owning subsidiaries located in high tax jurisdictions that perform research and development, manufacturing, or distribution activities, others have FSA-owning subsidiaries located in tax haven countries that are no more than a mailbox. Clearly, tax avoidance plays a role in FSA ownership structures. However, very little is known about FSA ownership outside of what is reported in the media because of tax avoidance.

My dissertation examines three questions related to MNE internal FSA ownership. First, how do MNEs internally organize ownership of their FSAs? Second, how do FSA characteristics affect MNE choice of FSA ownership structure? Third, how does FSA ownership affect subsidiary innovation? I also explore the role of tax haven FSA ownership.
For this research, I hand-collected a unique, confidential panel dataset on the internal transactions of 102 MNEs and their subsidiaries from 1997-2012 from transfer pricing reports and intra-firm contracts. The dataset includes detailed data on the internal economic ownership of FSAs, contracts between the FSA owners and users that clearly delineate the rights and responsibilities of each party, M\&As, changes in ownership structure, tax haven ownership, financials, and product flows. I combined this data with data from the United States Patent Trademark Office and used the combined data to construct MNE-level and subsidiary-level datasets. The following provides a brief summary of each study.

\section{Summary of Studies}

A large stream of research studies the choice between markets, hybrids, and hierarchies as external versus internal ownership decisions by firms. In reality, the same types of decisions occur routinely within MNEs. I identify four mutually-exclusive types of FSA ownership structures that MNEs use: (1) sole ownership, where one entity within the MNE owns the rights to all of the MNE's FSAs; (2) shared ownership, where two or more entities co-own all of the MNE's FSAs; (3) separate ownership, where two or more entities within the MNE own different FSAs; and (4) mixed ownership, where two or more entities within the MNE share ownership of at least one FSA and at least one entity within the MNE owns a separate and distinct FSA. The structures trade off market-like incentives with coordination and control.

The next study investigates how the characteristics of the FSAs owned by the MNE are correlated with the choice of ownership structure. Because FSAs are often costly to develop and maintain, firms have an interest in creating internal structures that provide high-powered incentives for subsidiaries to invest in FSAs. Property rights theory suggests that in an exchange relationship, the party whose contribution to the creation and maintenance of the asset should have control rights to the asset (e.g., Grossman \& Hart, 1986; Hart \& Moore, 1990). However, MNEs must balance these considerations against other potential advantages such as reduced administrative and monitoring costs, reduced bargaining problems, tax minimization, and greater internal knowledge flows. The findings indicate that MNEs with independent and easily codifiable FSAs, such as trademarks, are more likely to use internal FSA ownership structures that provide market-like incentives. In contrast, MNEs with complimentary or tacit FSAs, such as product innovation, are more likely to use internal FSA ownership structures that facilitate knowledge sharing and coordination within the firm. The results suggest that the choice of having a tax haven FSA owner is not important to the firm's choice of internal FSA ownership structure. 
The final study investigates the effects of FSA ownership on subsidiary innovation. For example, I examine whether firms that transfer FSA ownership away from R\&D subsidiaries to tax haven subsidiaries create incentive problems with regard to future innovative activity. The contractual relationships between FSA owners and FSA users reveal the formal network of intrafirm exchange relationships, centered around the FSA owners. I study the effects of two aspects of the MNE network on subsidiary innovation: (1) the roles of the subsidiaries, in particular whether or not the subsidiary is a FSA owner; and (2) the contractual relationships, which form network linkages amongst the entities. Through the ability to appropriate income from the asset and the ability to control the asset and its strate-

gic future development, ownership incentivizes investing in the creation and maintenance of the asset (Grossman \& Hart, 1986; Hart \& Moore, 1990). I find that subsidiaries that own the rights to FSAs are significantly more likely to produce technological innovations. Furthermore, transferring ownership away from a subsidiary significantly reduces its innovative outcomes. I also study the contracting relationships and whether it matters with which entity another contracts. When subsidiaries contract with pure tax haven FSA owners, subsidiary innovative output declines. In contrast, innovative output is not adversely affected when subsidiaries contract with parent FSA owners. The results suggest that when ownership is granted to pure tax haven subsidiaries, MNEs are challenged not only by the normal complexities of managing innovation, but also by the negative incentive effects that stem from assigning FSA ownership to non-value-generating units within the firm.

\section{Contributions}

This research makes several significant contributions to our understanding of the internal organization and management of MNEs. First, I contribute to the theory of the MNE by shedding new light on how FSAs are internally organized, developed, and managed within MNEs. Due to data limitations, previous empirical research in economics and strategy has not been able to open up the black box of internalized transactions. Although a great deal of research has examined the importance of firm FSAs, little is known about the ownership of FSAs within the MNE. Second, I extend property rights theory to inside the firm and identify four ways in which MNEs structure ownership of their FSAs. The four modes have different implications for control, coordination, incentives, and knowledge sharing within the MNE. Third, this research deepens our understanding of the internal organization and network structure of the MNE. FSA owners, as the entities that contract and license FSAs to other entities within the firm, are centrally positioned in the MNE internal network of financial, knowledge, and product flows. The internal allocation of property rights to FSAs determines subsidiary access to resources and control over key assets. Fourth, by investigating how subsidiary ownership of FSAs affects innovation, this research enhances our understanding of the relationship between internal governance of FSAs and the generation of future FSAs. Finally, this work extends the literature on transfer pricing, which has focused on prices of transactions, profit shifting, and tax avoidance by examining the operational consequences of tax havens.
Understanding the ways in which firms internally organize and manage their FSAs is important for scholars, practitioners, and policy makers alike. For policymakers, internal FSA ownership and contract and licensing arrangements have been the subject of much scrutiny by governments around the globe. FSA ownership has a significant effect on government revenues. Understanding the factors that drive the selection of FSA ownership structures can provide insight into the types of policies that can attract MNEs to

\section{References}

Bergin, T. 2012. Special report: How Starbucks avoids UK taxes. Reuters. October 15, 2012.

Ethier, W. J. 1986. The Multinational firm. The Quarterly Journal of Economics 101(4): 805-834.

Grossman, S., \& Hart O. 1986. The costs and benefits of ownership: A theory of lateral and vertical integration. Journal of Political Economy 94: 691-719.

Hart, O., \& Moore, J. 1990. Property rights and the nature of the firm. Journal of Political Economy 98: 1119-1158.

Levin, C., \& McCain, J. 2013. Offshore profit shifting and the U.S. tax codepart 2 (Apple Inc.). Memorandum to Members of the Permanent Subcommittee on Investigations. May 21, 2013.

Thompson, M. 2012. U.K. targets Google, Amazon and Starbucks on taxes. CNN Money. December 3, 2012.

Catherine Magelssen is an Assistant Professor of Strategy and Entrepreneurship at London Business School. Her research studies MNE strategy and intra-firm relationships. In particular, she explores how firms develop, organize, and manage their intangible assets. Her current research focuses on how firms allocate control over their intangible assets to entities within the firm and the strategic implications for firm knowledge sharing, innovation, and growth. 